\title{
Gendering the Narrative of the Irish Crisis
}

\section{Mary P. Murphy}

To cite this article: Mary P. Murphy (2015) Gendering the Narrative of the Irish Crisis, Irish Political Studies, 30:2, 220-237, DOI: 10.1080/07907184.2015.1022866

To link to this article: https://doi.org/10.1080/07907184.2015.1022866

\section{曲 Published online: 07 Apr 2015.}

Submit your article to this journal




\title{
Gendering the Narrative of the Irish Crisis
}

\author{
MARY P. MURPHY \\ Department of Sociology, National University of Ireland Maynooth, Maynooth, Ireland
}

\begin{abstract}
Adding a gender dimension to the story of the Irish crisis deepens our understanding of crisis and necessary responses. Using gender both as category and process we see clear gendered patterns throughout the Irish crisis including patterns of gender inequality in gendered institutions and changes in the process of gendered agency. Reviewing the extent to which Irish political and public spheres, banking and budgetary processes are gendered raises questions about how this impacts on post crisis outcomes. The gendered lens draws attention to the risks inherent in hyper-masculine institutions and culture and questions whether greater gender balance might alter the risk oriented culture of Irish financial services. It also draws attention to the gendered nature of Irish austerity budgets which disproportionately impacted women, and low income women in particular. The crisis also impacted on feminist agency. Examining women's political agency in the context of the crisis we find examples of defensive agency that sought to protect women's interests from fiscal retrenchment. These exist alongside examples of offensive feminist agency that use the crisis as an opportunity to strengthen gender equality in the political and policy processes. We find the gender infrastructure negatively impacted but despite such damage, we find feminist agency remains crucial to realising gender equality in public and private decision-making and despite the crisis, hopeful signs of renewed feminist agency are present.
\end{abstract}

Keywords: Ireland; banking crisis; gender; gendered institutions; defensive and offensive agency

\section{Introduction}

The social consequences of the Irish economic and social crisis have been severe, especially for women (Barry \& Conroy, 2013); however, gender has not been a variable in most studies of the Irish banking and economic crisis. Recent articles in Irish Political Studies have focused on lessons from the Irish crisis. From a behavioural economics perspective, Lunn argued problems associated with the crisis need to be accurately identified in order to translate into lessons. Referring to the variable

Correspondence Address: Mary P. Murphy, Department of Sociology, National University of Ireland Maynooth, Maynooth, Ireland. Email: mary.p.murphy@nuim.ie 
'behavioural convergence' as a contribution to the crisis he left unexplored how homogeneity of boards and gender inequality in governance may have contributed to Irish herding and group think (Lunn, 2013: 486). From a political science perspective, Chari and Bernhagen (2011) concluded that the role of lobbying, elite integration and the structural dependence of the Irish state on a thriving financial and property market offer explanatory potential for the Irish banking crisis but they offered no gendered analysis of elite power perspectives. We aim to supplement the analysis of the Irish crisis with the missing variable of gender. We do not argue gender inequality was a direct cause of the Irish banking and fiscal crisis but that an understanding of the relationship between gender and crisis enhances capacity to resolve and prevent crisis. We also examine the impact of the crisis on women's feminist agency. While acknowledging how crisis and austerity have damaged gender infrastructure, the paper also examines how feminist agency has used crisis-related opportunities to rectify power inequalities and gendered deficits in public life.

Section 2 outlines why gender framing of the crisis is necessary and stresses the need to avoid both essentialism and simplistic gendered explanations of the Irish crisis. The first half of the paper focuses on gendered institutions; Section 3 examines patterns of gender inequality in political and public spheres; Section 4 reviews the Irish banking crisis through a gendered lens and Section 5 examines gendered outcomes of austerity. The second half of the paper then turns to women's political agency in the context of the crisis. Section 6 examines evidence of defensive agency around women's interests and then examples of offensive feminist agency where crisis was used as an opportunity to strengthen gender equality in the political and policy processes. Section 7 provides a short conclusion to the paper. The paper draws primarily on secondary sources and primary data collected from public sources including government, non-government organisations, media websites and publications as well as 2014 interviews with feminist actors and participant observation.

\section{Why Gender Matters}

Various contributors to a 2013 Irish Political Studies special edition Politics and Gender on the Island of Ireland co-edited by Buckley and Galligan made the argument for studying issues of power, politics and policy through the lens of gender. This article continues their approach treating 'gender' as both a category of analysis (structure) and a process of change (agency). Arguing for a gender frame (Ridgeway, 2011) does not mean stressing female under-representation as an explanatory factor in the development of the Irish or global crisis. The argument is not that financial governance was more male dominated in Ireland than in other countries or that processes of financial management and economic policymaking became more male dominated post crisis than they had been before the crisis. Indeed it is not possible to show such correlation between gender inequality and crisis; analysis of EU data banks shows cross-national variation in crisis is not linked independently with variations in female representation and there is no correlation between countries with the most severe crisis and levels of gender inequality. ${ }^{1}$ Patriarchy alone does not have 
explanatory power, it must be understood in the context of the causal impact of financial deregulation and a more deregulated neoliberal form of capitalism (Fraser, 2013).

Nonetheless, it is still relevant to examine the crisis from the perspective of gender as a category and recognise 'that organisations institutionalise definitions of masculinity, constructing gender cultures and defining gender-appropriate jobs that reflect and advance masculine norms' (Buckley \& Galligan, 2013: 316). Following Connolly (2013) our starting point is that power is gendered and gender is present in the processes, practices and distribution of power (Acker, 1992). Connolly (2013) describes gendered institutions as 'gendered in their formal and informal rules and culture' with a masculine culture which makes them 'unfriendly' institutions for women. Rai (2010) highlights how institutional cultures are almost always gendered and reproduce power inequality by normalising certain norms and rendering others marginal. Political science is ambiguous about whether more women in senior positions actually lead to different and better decisions being made (Dahlerup, 2006). Waylen (2012: 5) focuses on the critical mass needed to achieve 'substantive representation' and the role of critical actors in achieving policy change. Philips (1995) is aware of the rigidity of political institutions and the difficulty of impacting on the practice of deeply gendered institutions which impede critical actors (men and women) from achieving quality goals. For others, more women in politics appears to make a substantive difference to issues such as childcare, health and social protection (Wängneurd \& Sundell, 2012), and to changes in parliamentary culture and the process and quality of decision-making (Lyn, 1994; Broughton \& Zetlin, 1996; Lovenski \& Norris, 2003).

A significant literature argues women's presence in board rooms alters the process of decision-making (Terjesen et al., 2009). While not necessarily less risk adverse, women are more active and independent as board members and directors with positive implications for overall risk management processes: women tend towards more use of committees, weigh long-term priorities and pay more attention to audit and risk oversight and control (Brown et al., 2002). Female directors have a significant impact on board inputs and firm outcomes; they bring a wider diversity of talent; influence male directors norms and cultures; allocate more effort to monitoring and the absence of 'old boys club' networks makes independent monitoring more likely (McKinsey, 2007; The Bottom Line, 2007).

Analysis of gender inequality in banking concludes more women in senior positions is key to realising economic stability and sustainable growth (EC, 2010; Treasury Committee, 2010). Hyper-masculinity means certain essentialised masculine dispositions are privileged and powerful in the world of finance (McDowell, 2010). Addressing the formation of culture in institutions means paying attention to how business education produces classed and gendered understandings of appropriate and desirable workplace personas in financial services (Hall, 2013: 236), it also means paying attention to gender balance in governance. Commenting on the hypermasculinity in global banking Christine Lagarde, Managing Director of the International Monetary Fund, advised (Lichfield, 2011: 1) 
the 2008 financial collapse was, at least in part, driven by the aggressive, greedy, testosterone-fuelled mood of male-dominated, hi-tech trading rooms .... I honestly think that there should never be too much testosterone in one room.

Michel Bariner, EU Internal Markets Commissioner argued, 'enhanced gender equality in banking governance is also an opportunity to address the group think that was a major factor behind the crisis affecting the global financial sector' (Spectrum, 2011: 8). The EU Capital Requirements Directive (CRD IV) now requires gender quota targets in banking governance processes (Irish Banking Federation, 2013).

\section{Gender in Irish Political, Economic and Public Spheres}

The International Committee on Civil and Political Rights 2014 report on Ireland strongly recommended action on gender equality and greater participation of women in public and private life in Ireland (CCPR, 2014: 3). With only 93 women TDs since 1918, Ireland's record is truly abysmal, only 5.4 per cent (262 of a total 4746) parliamentary seats filled since 1918 have been occupied by women (Buckley \& McGing, 2012: 222 (updated to July 2014)). The pattern at local level is broadly similar, suggesting no pipeline through local government to national government. The absence of women in parliament feeds through to a lack of women in cabinet. Up to 2012 Ireland had only 22 women ministers since 1922 or 6 per cent of the 181 ministers (Buckley \& McGing, 2012) and these portfolios follow gendered patterns (Connolly, 2013). A July 2014 cabinet reshuffle added two new female ministers to this total.

While the Icelandic response to the banking crisis had a gendered dimension (Tomasdottir, 2011) there was little mainstream Irish reaction concerning gender inequality in the context of crisis. Gender-specific topics garnered minimal interest in the 2011 election campaign and the percentage of women candidates decreased 2 per cent from the 2007 election and was the lowest since 1989 (Buckley \& McGing, 2012: 231). Only 15.2 per cent of candidates (86 out of 566) were female and only 25 out of 166 , or 15 per cent of the 2011 parliament, were women, leaving Ireland globally ranked 78th for the percentage of women in national parliament. In May 2014 local authority elections women comprised 20 per cent of candidates and 20 per cent of those elected. This increase from 16 per cent in the previous election reflected political parties need to invest in women candidates in the context of incoming gender candidate quotas for Dáil elections. Only one in eight of those negotiating the 2011 five-year Programme for Government were women, only two women were appointed to the 15 new cabinet ministerial posts, and their appointment was to social rather than economic cabinet portfolios (Connolly, 2013). In a 2014 Cabinet reshuffle, the new female Tanaiste Joan Burton T.D. had an immediate impact and the number of female cabinet ministers doubled to four.

It is not just politics. Table 1 demonstrates that the absence of women in the political world is reflected in the wider economic and business spheres. There is no 
Table 1. EU database of women and men in senior decision-making, EU, Ireland and Finland 2011

\begin{tabular}{lccc}
\hline & EU $(\%)$ & Ireland (\%) & Finland (\%) \\
\hline Parliament & 24 & 15 & 40 \\
Cabinet & 27 & 13 & 55 \\
Senior bureaucrats & 26 & 19 & 26 \\
Supreme Court & 32 & 26 & 26 \\
Central Bank & 18 & 15 & 31 \\
Largest quoted companies & 12 & 8 & 26 \\
\hline
\end{tabular}

Source: http://ec.europa.eu/justice/gender-equality/gender-decision-making/database/publicadministration/national-administrations/index_en.htm (accessed 28 Nov. 2012).

statutory or mandatory requirement for gender parity on state national or local partnership boards albeit there is a voluntary 40 per cent gender quota on boards or committees. A 2012 OECD study ${ }^{2}$ used 2009 data to place Ireland 26 out of 34 countries for the representation of women in our top private companies with women taking up just 6.9 per cent of private company board seats. Just 9 per cent of board positions in the top companies in Ireland's stock exchange are held by women. In public companies, where a voluntary target of 40 per cent applies, 34 per cent of board members are women (NWCI, 2014).

Irish political culture mirrors institutional politics and the absence of women in formal politics reflects an absence of women in the broader political and public sphere and media institutions (Ridgeway, 2011; O'Brien, 2014). Absence of women's voice in Irish public debate about the crisis was illuminated in an early example, a 2009 public event, '4 Angry Men', attended by over 1,200 in Dublin's National Concert Hall and repeated with larger audiences in 2012. The 'angry men' referred to four male authors of four political economy books concerning the crisis. This pattern continued. By late 2012, of more than 20 books related to the crisis, only three were co-authored and two fully authored by women. Broadcast media surveys in 2010 and 2012 showed less than one in four voices on air are women (NWCI, 2013). One in every 10 panellists on the Prime Time current affairs coverage of the 2011 General Election on RTE 1 was a woman (O'Brien, 2014). Further analysis showed $2 / 3$ of radio current affairs panellists were men, and that middle-aged women were found to be most under-represented (Suiter, 2013). Social media appears to replicate the gendered inequality of print and broadcast media. Blogs are often gendered spaces with hidden gender barriers (Bua, 2009). Economic commentary in blogs is dominated by men, in one month (September 2009) ProgressiveEconomy.ie had an average one woman for every six male commentators and IrishEconomy.ie one for every 10. Political blogs (politics.ie, politico.ie, politicalreform.ie) followed similar patterns of gendered activity. Collective letters to newspapers have become a feature of political debate in the recession. 
Table 2. Gender analysis of public signatories to Irish Times 2009-2012

\begin{tabular}{lcccc}
\hline Public Letters in Irish Times 2009-2012 & All & Women & Men & \% women \\
\hline Anti-NAMA & 47 & 7 & 39 & 15 \\
Alternative Keynes & 28 & 2 & 26 & 7 \\
Plan B & 66 & 23 & 43 & 35 \\
Suspend promissory note & 57 & 23 & 34 & 40 \\
Investment strategy & 35 & 7 & 28 & 20 \\
\hline
\end{tabular}

Source: Authors own calculation.

These have lower entry barriers, but Table 2 shows signatories to such collective public letters are also heavily biased towards men. The absence of women from current affairs not only limits democracy, it biases media commentary against a full exposition of the crisis (Fischer, 2012; O’Brien, 2014).

\section{Gendering the Story of the Irish Banking Crisis}

TASC (2010) highlighted a significant overlap between banking and economic elites; over half of 35 dominant Irish economic actors held board positions in at least one of Ireland's four largest financial institutions. Only one in nine of this power elite are women. They conclude that such gender imbalance and lack of social diversity tends towards 'group think' and decision-making cultures that prioritise consensus while ignoring alternative evidence, an observation borne out by the international literature (Terjesen et al., 2009).

Irish banks are gendered institutions. At the onset of the crisis in 2008 there was no woman Chief Executive Officer among the six Irish banks, the sole woman Chairperson was Gillian Bowler in Irish Life \& Permanent PLC. A 2011 review of the composition of the boards of the Irish banks shows Bank of Ireland (BoI) had one woman in nine board members, Northern Bank had no women in 10 board members and Ulster Bank had four women in 14 board members (Spectrum, 2011). This mirrors UK patterns of gender imbalance in senior management within banks where women are prominent in administrative and secretarial jobs but significantly underrepresented in managerial and senior level jobs (Metcalfe \& Rolfe, 2009; ILM, 2012). 70 per cent of the 40,000 members of the Irish Bank Officials Association are women and one in every 28 women employed in Ireland works in a high street bank, but few make it into banking management (Salamonska et al., 2008). That Iceland's crisis era Central Bank governance was dominated by women (43 per cent male) suggests gender parity was no guarantee against bad governance. What is striking nonetheless is the degree of gender inequality throughout the key stage-posts of the Irish banking crisis: the night of the bail out; the banking crisis reviews; the banking inquiry. We might ask whether this, in anyway, coloured the story of the Irish crisis? 
Over 2015 an Irish parliamentary inquiry will examine responsibility for devising the 28 September 2008 bank bailout. While details are still vague, it is entirely possible that not one woman was present from any of the government, banking, legal, advisory or civil service sectors involved in that decision. International legal firm Arthur Cox provided separate male advisors to then Taoiseach Brian Cowen, then Minister for Finance Brian Lenihan, and to the bank representatives: AIB (Allied Irish Banks) and BoI Chairmen and Chief Executive Officers (all male). There was only one woman in 12 at senior Assistant General Secretary level in the Department of Finance and the Board of the Central Bank. Political responses to the banking crisis included three separate reviews of the banking system and a review of the Department of Finance. The government appointed exclusively male teams to head the three reviews of the banking crisis (Honohan, 2010; Regling \& Watson, 2010: Nyberg, 2011). Wright (2011) produced a fourth report examining deficiencies in the Irish Department of Finance. These four reports were gender blind. While they reflect on the degree to which group think, explicitly associated in academic literature with a lack of diversity, was a contributory factor in the banking crisis, in an ironic exercise of group think and despite relevant academic and international policy literature, none of the reviews made gender or diversity a variable in their analysis. 24 May 2014 saw the establishment of a Joint Oireachtas Committee to inquire into certain aspects of the Irish banking crisis and controversy about the gendered composition of this committee (which at one point comprised an all-male committee of nine controlled by opposition parties). On 12 June 2014, the government, primarily motivated to maintain control of inquiry, nominated two extra members, one of whom was a woman leaving a 10:1 gender balance. ${ }^{3}$ This consistent lack of gender parity in all aspects of the banking crisis story should at least provoke questions. However, lack of parity has been rarely considered problematic from either symbolic, instrumental or substantive perspectives and gender has rarely been a variable in any analysis of the banking crisis. A 2013 report exploring terms of reference for the banking inquiry, for the Minster of Public Expenditure and Reform (Oireachtas Library, 2013), recommended examination of gender but this did not translate into the final subject matter of the inquiry. While gender is an implicit concern of corporate governance and business models (item number 6 of the terms of reference of the Banking Inquiry ${ }^{4}$ ), the lack of explicit examination of gender inequality in Irish governance may limit capacity to learn from the crisis. The response of Irish banks to the gender governance targets in the EU Directive on capital requirements could be described as minimalist at best. The industry argued 'we do not see merit in having any diversity provisions introduced into the Code that place an undue emphasis on gender diversity' (Irish Banking Federation, 2013: 13), demonstrating little appreciation that gender balance might strengthen corporate governance.

\section{Gender and Austerity Budgets}

Feminist analysis anticipates that, given women's lack of power, the crisis is likely to be used as an opportunity to roll back gender equality. There are clear gendered 
implications from a government strategy that focuses on public expenditure cuts as the primary tool to manage fiscal correction. Simply put, more women are employed in the public sector, more women use public services and more women claim social welfare payments. (Smith \& Bettio, 2009; Karamessini \& Rubery, 2013; Villa \& Smith, 2013). The gender impact of the present crisis differs from previous crises. Initial gender gaps in employment and poverty tended to diminish not because of progress in gender equality but due to a levelling down of employment and decline in earnings among men. As austerity digs in women are more severely affected. Fiscal consolidation curtails service sector jobs, public sector job cuts increase and social expenditure becomes more restrictive and selective. Reductions in social expenditure contract key social services many of which have gendered patterns of use; this puts pressure back onto communities and families where women traditionally serve as care buffers and managers of much reduced family budgets. This section briefly outlines and draws out the gender implications of budget changes including changes to lone parent's payments and child benefit which particularly impact on women $^{5}$ (Murphy, 2014).

We first draw attention to the gendered nature of key institutions governing the Irish budgetary process. Irish budgets were conducted under the shadow of the October 2010 sovereign bailout negotiated with the Troika; the European Central Bank (fronted by Klaus Masuch), the European Commission (Istvan Szekely) and the International Monetary Fund (Ajai Chopra). When out of town, the Troika left Nigel Nagarajan as their Ireland representative in residence. Gender frames are very visible in the public narrative of the Troika (Ridgeway, 2011). The following newspaper bylines (21 October 2011 Irish broadsheets) describe a Troika visit using a highly gendered discourse; 'Neither fits the picture of an "economic hit man", ... 'the European Commission's man in charge' ... 'Troika headmasters confirm their model pupil is getting a good report'... 'When the ECB's man was asked yesterday'... 'The troika men stressed again and again'. In 2010 the Troika originally negotiated with a primarily male team of Irish politicians and bureaucrats, post 2011 a new domestic fiscal and budget policy process emerged that was also gendered in culture and practice. The Economic Management Council (EMC), described as 'the core of the Government' by Kinsella (2013), includes the Taoiseach, the Tánaiste, the Minister for Finance, and the Minister for Public Expenditure and Reform. Originally an all-male council, this appeared to quickly consolidate into a gendered institution, the 2014 reshuffle saw Tánaiste Joan Burton join the EMC.

In May 2009 social assistance payments for unemployed people under age 24 were halved with younger lone parents protected from this age-related approach, however, in Budgets 2010 and 2011, all working age social welfare payments including the One Parent Family Payment (OPFP) were cut by 4 per cent. A series of Budget 2009 and 2012 structural reforms to Jobseeker payments made it more difficult for part-time and atypical workers to qualify for Jobseeker payments, and reduced the level of payment due. These structural changes are gendered: more onerous eligibility criteria make it harder for women - over-represented in low paid, atypical and 
part-time work - to qualify for payment, and where they do, they receive less income support. A 2010 cut to the minimum wage (since reversed) and the introduction of the Universal Social Charge (since modified) were both regressive for the low paid, the majority of whom were women (Barry \& Conroy, 2013).

Among considerable changes to the OPFP were two key structural reforms; earned income disregards for the OPFP allowance were to be made equivalent to jobseeker income disregards and eligibility for the OPFP was restricted to parents whose youngest child is seven or younger. Budget 2012 announced phased reductions in income disregards; to reduce by 60 per cent by 2016, levelling it down in line with Jobseekers Allowance (in a policy reversal Budget 2015 did not implement the final cut of $€ 30$ to the OPFP income disregards). Budget 2012 also announced the intention to restrict OPFP but in 2013 the government subsequently announced a mitigating 'Jobseeker Transitional' arrangement for parents whose youngest child was between 7 and 14, exempting them from some Jobseeker conditionality requirements and enabling them to continue a part-time work pattern. When their youngest child reaches age 14 , they will transfer to full conditionality under the main Jobseeker scheme.

Budget 2012 saw controversial cuts in social assistance entitlements related to disability and caring. Entitlement to Carer's Allowance was made more restrictive for non-residential carers (80 per cent of recipients are women). Income received as a home help is now assessed in means-tests, as are social welfare payments for carers; again this impacts primarily on women combining both caring and parenting roles. Home help budgets were also cut. Budget 2013 announced a cut in the Respite Care Grant, women comprise 64 per cent of carers and are disproportionately impacted. Budget 2014 was announced on 15 October 2013 (a change of date occasioned by the new European Semester). The overall focus of the budget was to reduce younger and older people's income supports but also saw a specific lone parent tax credit worth $€ 1,650$ per annum restricted to the main carer, and taxation and restriction of maternity benefit.

Budget 2009 announced a phased withdrawal of universal Child Benefit (CB) for children aged 18. Universal Early Childcare Supplement was halved, then abolished at the end of 2009; however, in 2010, a universal (school) year of free half-time preschool Early Childhood Care and Education was introduced. CB was cut by a further 10 per cent in 2010. Up to this point, social welfare dependent families had been protected from the impact of CB cuts with increases in other child-related entitlements. But from 2011, when CB rates were cut by a further 7 per cent, the poorest families were not protected. Budget 2012 announced the phasing out of higher CB rates for larger families and introduced cuts in other mean-tested child education income supports. Further CB cuts were implemented in 2013, so that cumulatively, rates have been cut by 22 per cent for smaller families, and by a third for larger families. Further cuts in means-tested child income supports were implemented in 2013 but Budget 2015 signalled a reversal with a $€ 5$ increase in CB.

Rent Supplement (RS), an income support for low income tenants in the private sector, has also been a focus of austerity reforms. At the same time, the capital budget for social housing construction was severely curtailed. These reforms 
'ghettoise' the most vulnerable tenants in the low rent markets and have contributed to the increase in family homelessness experienced in 2014. Lone parents comprise a significant proportion (over 50 per cent) of both the social housing list and RS recipients, and are disproportionately impacted. Various statutory initiatives have diminished civil society's capacity to be socially transformative and women's interest groups and service delivery groups have been hit disproportionately in this regard (Murphy, 2012). Cuts of up to 40 per cent can be compared to wider cuts in government expenditure of 7 per cent over the same period, with domestic violence refuges and childcare supports particularly impacted (Harvey, 2014). The disproportionate gendered impact of budgets was highlighted by TASC (2011), Barry and Conroy (2013) and Murphy (2014) and confirmed in 2014 by both the ESRI (Economic and Social Research Institute) and the Equality Authority which both showed that tax and benefit changes have reduced the individual income of women more than men, particularly among those on lower incomes (Keane et al., 2014: 5).

\section{How Has Crisis Impacted on Women's Agency?}

Understanding gender as a process suggests that 'female political agency, through the activities of politicians, civil society and feminist actors, can work to establish practices and rules that recast and re-inscribe the gendered foundations of democratic politics, political institutions and the state' (Buckley \& Galligan, 2013; 316). The absence of women in the public sphere (described in Section 3) does not mean women were silent or passive in response to crisis. We now look more closely at women's interests and feminist agency in the aftermath of the crisis. Buckley and Galligan (2013: 1) are concerned with 'uncovering the marginalised experiences of women in modern politics on the island of Ireland' and 'efforts to challenge the masculinised status quo'. They use a specific and relatively narrow definition of the term 'political agency' as 'the extent to which women feel enabled to make claims upon democratic politics, the state and political institutions and, in doing so, shape political outcomes'. Adopting this relatively narrow use of agency this section examines women's political agency in response to crisis. Following Ellison (2000) we first analyse instances of defensive agency and then, instances of proactive or offensive agency.

\subsection{Defensive Women's Agency}

Section 5 explained how austerity budgets disproportionately impacted on women, the scale of the expenditure cuts suggests we should expect defensive public reaction from women? Section 5 also outlined examples of the disproportionate cuts to women's groups which undermined capacity to respond to gendered budgets. The considerable national and local agency outlined below needs to understood in the face of significant cuts to women's infrastructure. The NWCI (National Women's Council of Ireland) lost 35 per cent of its funding in 2012, a funding cut justified on grounds of prioritising front line service provision over advocacy or agency 
(Harvey, 2014: 76). One Parent Exchange Network (OPEN) likewise lost funding and many of its local affiliates disappeared. Women's refuges and shelters that provide domestic violence and childcare services experienced cuts of 40 per cent to their funding and found remaining funding restricted to service delivery, so that policy and advocacy work has diminished. This statutory policy to separate advocacy from service provision makes Ireland an outlier in European social policy and civil society, and means national and local women's groups are fire-fighting funding cutbacks while coping with pressures on services (Harvey, 2014: 40). This leaves some groups feeling suppressed or inhibited from dissenting against government policy. For some feminist groups like Banulacht and Kibarrack Local Education for Adult Renewal, the combination of cuts and funding restrictions left them so unable to meet their core objectives that they closed the project rather than accept disempowering terms and conditions. Other women's projects including the Women's Health Council were closed under government austerity budgets while broader equality and human rights infrastructure (including the Irish Human Rights Commission and The Equality Authority) were also significantly undermined.

The NWCI, Feminist Open Forum, Irish Feminist Forum, Banulacht, Women of Debt Justice Action, Irish Congress of Trade Unions 'Fighting Back' Biennial Women's Conference and many others have engaged in gendered responses to the crisis. Trade Union TV (Geraghty, 2012) shows a rich record of women's agency in public protest over the crisis with women dominating many local, national and sectoral protests in relation to carers' payments, child income support, child care, social service, health and water issues. These campaigns are not necessarily framed as gender-equality campaigns rather they are often sectoral or specific campaigns and sometimes framed as broader anti-austerity campaigns. The following two examples of gender-specific campaigns; against cuts to lone parent payments and CB, demonstrate strong and partially successful agency, allow deeper examination of gendered defensive campaigns.

Single Parents Acting for Kids (SPARK) and OPEN campaigned against reforms to the OPF outlined in Section 5. The Seven is too Young campaign was fronted by OPEN, and fought the introduction of withdrawal of OPF from lone parents whose youngest child was age seven or over. They argued 'this unnecessary reform is untimely, ungainly and ill-fitting a government which has both international and national obligations to reduce poverty, look after children and protect the most vulnerable' ${ }^{6}$ OPEN managed to secure crowd sourced funding for an innovative bus-stop advertising campaign and worked with other groups including the NWCI and Children's Rights Alliance (CRA) to target politicians in particular lobbying local constituency offices. They worked in parallel with SPARK a more militant group of single parents, who organised a 2013 protest, more directly confronted politicians and conducted a lively face book campaign. SPARK continue to organise into 2015. The overall campaign was framed around government's commitment to protect the vulnerable and was at least partially successful in at least mitigating the cuts to OPFP.

Section 5 outlined significant cuts to CB. Nonetheless, unlike the UK, Ireland survived six years of austerity budgets without taxation or means testing of the universal 
CB. In the period leading up to, and after Budget 2009, both the NWCI and the CRA were in the forefront of an alliance opposing any cuts in CB. A NWCI (2009) briefing paper 'All the Children' championed CB as a universal gendered payment that directly supports mothers, assists childcare costs for working mothers and acts as a payment for those who care in the home. An NWCI membership survey showed $\mathrm{CB}$ to be a critical part of family income with 45 per cent attesting that cuts in $\mathrm{CB}$ would be a 'financial disaster' for their families. The CRA (2009) pre-budget submission strongly opposed any cuts, tax or means testing of $\mathrm{CB}$ and framed $\mathrm{CB}$ as a valued child-centred payment which supported universalism and horizontal distribution. It points directly to the electoral fall out 'taxing or means-testing CB would be deeply and politically unpopular' (CRA, 2009: 6). In $2011^{7}$ the 'Protest Against Cuts to Child Benefit' (established in April 2008 to fight initial cuts Early Childcare Supplement) used Facebook to great effect to organise protests and a 2012 petition with 28,000 signatures and worked with the NWCI to launch a successful media campaign against taxing or means testing $\mathrm{CB} .{ }^{8}$ These campaigns spoke directly to the political system holding it accountable to their commitment to protect the vulnerable, particularly children.

These campaigns show women's groups in a defensive position but at least partially successful in mitigating gendered cuts and also using a variety of traditional and innovative tactics to good effect. These include developing gendered alliances, street protests, active use of research, mobilisation of affiliates, pre-budget submissions, petitions and direct national and local lobbying of politicians. Facebook in particular played a significant role in enabling women working in the home to organise, such campaigns have longevity as they can be easily reignited. The CB campaign tactically demonstrated the electoral salience of women's budget cuts. In October 2014, the Tánaiste and Minister for Social protection confirmed governments commitment to universal CB and budget 2015 increased CB by $€ 5$, in November 2014 the remaining cuts to OPFP income disregards were withdrawn.

\subsection{Offensive Feminist Agency}

The defensive agency described above persists in the face of significant cuts to women's infrastructure. While gender is still not a significant part of the mainstream analysis of the Irish crisis (Caldwell, 2010), there is evidence of offensive agency where women are proactively agenda setting to tackle power inequality in gendered institutions. This section briefly reviews three offensive attempts to use crisis as an opportunity to advance feminist agendas concerning structural power inequality; equality proofing campaigns; gender quotas; the Constitutional Convention (CC).

As Keane et al. (2014: 12) observe gendered labour markets result in different income tax liabilities, entitlements to benefits, and impacts of public sector pay changes for men and women. The Irish state's record on the implementation of EU policies on gender equality 'can be characterised as a mixture of resistance and benign neglect' (Cullen, 2008: 2). Adoption of EU 'gender mainstreaming' changed little in Irish public policy, bureaucratic or political culture (McGauran, 2005). State 
capacity to analyse the gendered impact of the crisis is weak, the Gender Equality Division in the Department of Justice has tended to focus on international processes and the Equality Authority more on broad equality than specific gender issues. Despite the absence of statutory gender budgeting processes various Irish feminists analysed the gendered implications of austerity budgets and policy responses to the crisis (TASC, 2011; Barry \& Conroy, 2013; Murphy, 2014). Prompted by Barry and Conroy's (2013) extensive gender analysis, Irish Feminist Network led a broad-based initiative to promote equality proofing in the Equality Budgeting Campaign (2012). The campaign faces an uphill struggle as such tools are underdeveloped and lack legislative footing in the Irish context but the group did develop wide alliances around equality proofing, drew on academic resources and international experts, published campaign documents, lobbied, engaged in media work and used social media to promote equality proofing and the campaign objectives was debated in the Irish parliament. While not yet successful in the campaign's overall objective, the language of equality proofing is now at least evident in budget narratives.

Early in the crisis a 2009 parliamentary report from the Joint Committee on the Constitution advocated candidate quotas (Bacik, 2009). While government may have acted on these issues for other reasons, Buckley (2013) outlines considerable women's agency on gender candidate quotas including an NWCI appointment of a Women in Politics campaign coordinator and the emergence of lobby group 50:50 who campaigned for the implementation of measures to redress gender imbalance. Other developments include the 2011 award from Social Entrepreneurs Ireland to the project 'Women for Election' as well as individual political party projects where women's groups or individual critical actors have sought to advance gender parity strategies within political parties. In June 2011, Minister Phil Hogan announced that political party funding would be linked to gender balance of electoral candidates. Buckley (2013: 341) names economic crisis as part of the context that brought the issue of women's political under-representation to the forefront of politics (Buckley, 2013: 352), she argues the introduction and adoption of legislation on candidate sex quotas was facilitated by a

coming together of a constellation of pressures, notably a political reform discourse, the mobilisation of female collective agency through civic society groups, and elite support of the issue as a vehicle for projecting a reforming image.

In early 2012, the government established a CC to provide an opportunity for reflection and debate as to what, if any, modification and renewal was required for the 1937 Constitution. Civil society groups, including women's groups, while expressly excluded from membership, energetically engaged in this process making written submissions and presentations. The NWCI invested considerable staff and financial resources and consciously and proactively sought to advance gender equality through the CC. They commissioned a constitutional expert to identify how gender equality could be advanced through the CC (Brady, 2012), funded a national 
conference to gender the $\mathrm{CC}$ debate and directly participated as experts in the $17 \mathrm{Feb}-$ ruary 2013 CC meeting. The successful outcome was a recommendation to amend a constitutional clause which affirms the role of women in the home and to promote actions to encourage greater participation of women in public life. ${ }^{9}$ A feasibility study has been since commissioned by government to examine textual changes required to achieve gender-neutral language in the constitution; however, up January 2015 there is no time frame for introduction of the amendment, a formal Department of Justice and Equality review of an explicit provision for gender equality which was to be completed by 31 October 2014 remained unpublished in January 2015 .

\section{Conclusion}

These six examples highlight how feminist agency, while injured by crisis, is still very much alive post crisis. There is insufficient analysis in this short summary to claim a resurgence of feminist action in traditional and non-traditional forms. However, there is evidence of experimentation and new forms of networking and a sense of solidarity across women's issues, organisations and activists (Walby, 2011). It is difficult to distinguish how feminist actions differ before and after the crisis, to assess whether any change in patterns can be linked explicitly to the crisis or to explain how relatively strong feminist agency coexists with a disproportionally negative impact of austerity policies on women's infrastructure. Both established and new feminist actors are visible in campaigning and, despite tensions and differences, critical actors have ensured co-operation across campaigns. There is evidence of both a new generation of feminists 'stepping in' and an older generation perhaps 'stepping up' and of different and more open relationships between traditional non-government organisations and activist forums.

Both defensive and offensive campaigns show tensions in maintaining a focus on gender in broader campaigns. To maintain an explicitly gendered focus the Child Benefit campaign and the Seven is Too Young campaign worked with a limited range of actors and framed the campaigns around children. The budget proofing campaign is led by feminists but includes gender as part of a broader equality focus which maintains a range of alliances. Defensive campaigns are explicitly linked to the crisis and show women's groups using alliances, a mixture of traditional lobbying and newer social media campaign tactics. In some offensive campaigns the crisis was used as an opportunity to highlight and campaign for long standing demands; the gender quota campaign for example could largely piggyback on the larger crisisrelated political reform agenda (Buckley, 2013). Gender issues in the CC were not prompted by crisis but a by-product of a broader focus on political and constitutional reform. The increased use of Facebook and social media may be partially driven by resource deficits but would likely have been the case with or without the crisis. Women perhaps have a different pattern of social media use and the medium is an important mobilisation tool for women working within the home. Offensive feminism examples demonstrate considered engagement with tackling gendered institutions 
and deep structural legal and institutional barriers to gender equality. There is explicit use of national and international academic research as well as broad mobilisation and alliance building. At the same time the depletion of local and national resources has had real impact with less mobilisation and policy capacity in women's groups, particularly specialised domestic violence and rape crisis groups, and local groups report feeling increasing control within new local authority institutional arrangements.

This paper has argued that there is a value in studying the crisis through the lens of gender. Internationally there is considerable support for the view that the hyper-masculinity in banking at least contributed to the scale and nature of the crisis (Smith \& Bettio, 2009). A gendered narrative of the Irish crisis highlights that gendered institutions and cultures may have played some role in maintaining the climate of group think that was central to key decisions. Further, gendered budget processes led to negative distributional outcomes for women as well as a failure to utilise mainstreaming and proofing mechanism that might mitigate such impacts. The absence of women in economic, political and public life in Ireland was a reality leading up the crisis and during the crisis. There is little evidence that economic or political representation of women has changed significantly towards a more equal representation. While austerity has prompted defensive agency from women's interest groups and feminists, the crisis has also negatively impacted on women's collective infrastructure and capacity for agency. Feminist agency has offensively used the crisis as an opportunity to tackle gender inequality, however, gender analysis and public awareness of the gender impact of the crisis remains limited. Villa and Smith (2013) note how the crisis has occasioned a fundamental policy reformulation of all aspects of EU social policy including gender equality yet the Irish government made no genderrelated comment to the EU 2010 consultation on Europe 2020 reflecting the reality that EU policy on gender equality is not mainstreamed into Irish domestic policy. Arguments for women in senior political and economic decision-making and public sphere are more relevant than ever. Feminist agency remains crucial to realising these outcomes, the crisis has dented but not broken such agency.

\section{Notes}

1. http://ec.europa.eu/justice/gender-equality/gender-decision-making/database/politics/national-parliam ents/index_en.htm shows national variations in female representation. Iceland (60\% male) and Ireland ( $85 \%$ male) both experienced banking crisis but show a striking variation in gender representation in politics and business. Spain (61\% male) has relatively high gender parity, Portugal (71\% male) is near the EU 27 average of $74 \%$ male as is Greece (79\% male), while Cyrus is an outlier with $91 \%$ male.

2. http://www.oecd.org/gender/data/boardroommembershipbysex.htm.

3. Ironically, the circumstances of the nomination process provoked a side debate about the pressures for mothers in politics. http://www.politics.ie/forum/oireachtas/226844-seanad-full-time-job-e-g-susanokeeffes-absence-john-crowns-many-jobs-3.html.

4. http://www.thejournal.ie/banking-inquiry-expert-group-interim-report-1586232-Jul2014/.

5. Analysis drawn from budget statements over 2009-2015, http://www.finance.gov.ie/budget, supplemented with analysis, http://www.socialjustice.ie/content/budget-home.

6. http://www.svp.ie/Files/Documents/SEVEN-IS-TOO-YOUNG!.aspx. 
7. http://www.independent.ie/videos/irish-news/national-womens-council-and-child-benefits-protestgroup-pacub-28942655.html.

8. http://www.independent.ie/videos/irish-news/national-womens-council-and-child-benefits-protestgroup-pacub-28942655.html.

9. https://www.constitution.ie/NewsDetails.aspx?nid=aec54a46-3979-e211-a5a0-005056a32ee4.

\section{References}

Acker, J. (1992) Gendered institutions: from sex roles to gendered institutions, Contemporary Society, 21(5), pp. 565-569.

Bacik, I. (2009) Second Report Women's Participation in Politics, Joint Committee on Justice, Equality, Defence and Women's Rights, available at: http://www.oireachtas.ie/documents/committees30thdail/ justiceedwr/reports_2008/20091105.pdf (accessed 28 November 2012).

Barry, U. \& Conroy, P. (2013) Ireland in crisis 2008-2012: women, austerity and inequality, in: J. Rubery \& M. Karamessini (Eds.) Women and Austerity - The Economic Crisis and the Future for Gender Equality, pp. 186-206 (London: Routledge).

Brady, A. D. P. (2012) The Constitution, Gender and Reform: Improving the Position of Women in the Irish Constitution (Dublin: NWCI).

Broughton, S. \& Zetlin, D. (1996) Queensland ALP women parliamentarians: women in suits and boys in factions, International Review of Women and Leadership, 2(1), pp. 47-61.

Brown, D. A. H., Brown, D. L. \& Anastasopoulos, V. (2002) Women on Boards: Not Just the Right Thing ... But the "Bright" Thing (Ottawa, Canada: The Conference Board of Canada).

Bua, A. (2009) Realising On-line Democracy: A Critical Appraisal of Online Civic Commons, available at: www.compassonline.org (accessed 28 November 2012).

Buckley, F. (2013) Women and politics in Ireland: the road to sex quotas, Irish Political Studies, 28(3), pp. $341-359$.

Buckley, F. \& Galligan, Y (2013) Politics and gender on the island of Ireland: the quest for political agency, Irish Political Studies, 28(3), pp. 315-321.

Buckley, F. \& McGing, C. (2012) Women and the election, in: M. Gallagher \& M. Marsh (Eds) How Ireland Voted, pp. 222-240 (Basingstoke, UK: Palgrave Macmillan).

Caldwell, J. (2010) The Women who Forgot to Ruin Ireland, available at: http://www.theantiroom.com/ 2010/08/03/the-women-who-forgot-to-ruin-ireland/ (accessed 28 November 2012).

Chari, R. \& Bernhagen, P. (2011) Financial and economic crisis: explaining the sunset over the Celtic Tiger, Irish Political Studies, 26(1), pp. 473-488.

Children's Right Alliance (CRA) (2009) Position Paper on the Child Benefit Payment (Dublin: CRA).

Committee on Civil and Political Rights (CCPR) (2014) Final Report to Ireland from the Committee on Civil and Political Rights (CCPR/C/IRL/CO-4-11770-E) (Geneva: HRC).

Connolly, E. (2013) Parliaments as gendered institutions: the Irish Oireachtas, Irish Political Studies, 28(3), pp. $360-379$.

Cullen, P. (2008) Irish women's organizations in an enlarged Europe, in: S. Roth (Ed.) Gender Issues and Women's Movements in the Expanding European Union, pp. 83-100 (Oslo: Berghahn Press).

Dahelrup, D. (2006) The story of the theory of critical mass, Politics \& Gender, 2(4), pp. 511-522.

EC (2010) More Women in Senior Positions: Key to Economic Stability and Growth (Brussels European Commission Directorate-General for Employment, Social Affairs and Equal Opportunities, Unit G1), January.

Ellison, N. (2000) Proactive and defensive engagement: social citizenship in a changing public sphere, Sociological Research Online, 5(3), available at: http://www.socresonline.org.uk/5/3/ellison.html. (accessed 28 November 2012).

Equality Budgeting Campaign (2012) Equality Budgeting Campaign: An Information Booklet, available at www.equalitybudgeting.ie (accessed 28 November 2012).

Fischer, C. (2012) Opinion: time to correct imbalance of genders in news media, The Irish Times, 4 April. 
Fraser, N. (2013) Fortunes of Feminism: From State-Managed Capitalism to Neoliberal Crisis (New York: Verso Books).

Geraghty, P. (2012) Trade Union TV, available at: http://www.youtube.com/user/TradeUnionTVIreland (accessed 28 November 2012).

Hall, S. (2013) Business education and the (re)production of gendered cultures of work in the city of London, Social Politics, 20(2), pp. 222-241.

Harvey, B. (2014) Are We Paying for That; Government Funding and Social Justice Advocacy (Dublin: The Advocacy Initiative).

Honohan, P. (2010) The Irish Banking Crisis: Regulatory and Financial Stability Policy 2003-2008 (Dublin: Department of Finance).

ILM (2012) Women in Banking, Institute of Leadership \& Management, available at: http://www.i-lm.com/ downloads/Research_womeninbanking_march12.pdf (accessed 28 November 2012).

Irish Banking Federation (2013) Response to Central Bank Consultation on Board Diversity (Section 7) (Dublin: IBF).

Karamessini, M. \& Rubery, J. (2013) Women and Austerity : The Economic Crisis and the Future for Gender Equality (London: Routledge).

Keane, C., Callan, T. \& Walsh, J. R. (2014) Gender Impact of Tax and Benefit Changes: A Microsimulation Approach (Dublin: Equality Authority and ESRI).

Kinsella, S. (2013) Hearing show how democracy works, so let's have more of it, Irish Independent, 15 January, available at: http://www.independent.ie/opinion/analysis/stephen-kinsella-hearings-showhow-democracy-works-so-lets-have-more-of-it-28958972.html (accessed 20 December 2013).

Lichfield, J. (2011) The Monday Interview: Christine Lagarde, available at: http://www.independent.co.uk/ news/people/profiles/christine-lagarde-there-should-never-be-too-much-testosterone-in-one-room2206357.html 07 Feb 2011 (accessed 28 November 2012).

Lovenduski, J. \& Norris, P. (2003) Westminster women: the politics of presence, Political Studies, 51(1), pp. 84-102.

Lunn, P. D. (2013) The role of decision-making biases in Ireland's banking crisis, Irish Political Studies, 28(4), pp. 563-590.

Lyn, K. (1994) Power and influence in state legislative policymaking: the interaction of gender and position in committee hearing debates, The American Political Science Review, 88(3), pp. 560-577.

McDowell, L. (2010) Capital culture revisited: sex, testosterone and the city, International Journal of Urban and Regional Research, 34(3), pp. 652-658.

McGauran, A. M. (2005) The experience of gender mainstreaming the national development plan, Administration, 52(1), pp. 22-44.

McKinsey (2007) Women Matter: Gender Diversity, a Corporate Performance Drive (Paris: McKinsey \& Company).

Metcalf, H. \& Rolfe, H. (2009) Employment and Earnings in the Finance Sector: A Gender Analysis (London: National Institute of Economic and Social Research).

Murphy, M. P. (2012) Irish civil society in the shadow of the Irish state, Irish Journal of Sociology, 19(2), pp. $173-189$.

Murphy, M. P. (2014) Ireland's lone parents, social welfare and recession, Irish Community Development Law Journal, 3(2), pp. 6-20.

NWCI (2009) All Our Children (Dublin: NWCI).

NWCI (2013) Submission to Broadcasting Authority of Ireland (Dublin: NWCI).

NWCI (2014) Women on Boards, available at: http://www.nwci.ie/?/discover/what_we_do/women_in_ decision_making/women_on_boards (accessed 20 December 2014).

Nyberg, P. (2011) Misjudging Risk: Causes of the Systemic Banking Crisis in Ireland (Dublin: Department of Finance).

O'Brien, A. (2014) It's a man's world: a qualitative study of the(non) mediation of women and politics on prime time during the 2011 general election, Irish Political Studies, 29(4), pp. 505-521.

OECD (2012) Women on company boards, in: Entrepreneurship at a Glance 2012 (OECD Publishing), available at: http://dx.doi.org/10.1787/entrepreneur_aag-2012-23-en. 
Oireachtas Library (2013) Review of Banking Crisis Reports (Dublin: Minster of Public Expenditure and Reform Public Accounts Committee Inquiry into the Bank Bailout).

Philips, A. (1995) The Politics of Presence (Oxford: Oxford University Press).

Rai, S. M. (2010) Analysing ceremony and ritual in parliament, The Journal of Legislative Studies, 16(3), pp. 284-297.

Regling, K. \& Watson, M. (2010) A Preliminary Report on the Sources of Ireland's Banking Crisis (Dublin: Government Publications).

Ridgeway, C. (2011) Framed by Gender: How Gender Inequality Persists in the Modern World (Oxford: Oxford University Press).

Salamonska, J., Moriarty, E., Wickham, J. \& Bobek, A. (2008) Migrant Workers and the Financial Services Sector in Ireland (Dublin: TCD).

Smith, M. \& Bettio, F. (2009) Analysis Note: The Economic Case for Gender Equality (Brussels: European Commission).

Spectrum (2011) Irish Banking Officials Association Spectrum, December, available at: www.iboa.ie (accessed 28 November 2012).

Suiter, J. (2013) Research study finds that two in three voices on radio news and current affairs are male, Irish Times, 25 August.

TASC (2010) Mapping the Golden Circle (Dublin: TASC).

TASC (2011) Winners and Losers Equality Lessons for Budget 2012 (Dublin: TASC).

Terjesen, S., Sealy, R. \& Singh, V. (2009) Women directors on corporate boards: a review and research agenda, Corporate Governance: An International Review, 17(3), pp. 320-337.

The Bottom Line (2007) Corporate Performance and Women's Representation on Boards (New York: Catalyst), available at: http://www.catalyst.org/publication/200/the-bottom-line-corporate-performa nce-and-womens-representation-on-boards (accessed 28 November 2012).

Tomasdottir, H. (2011) A feminine response to Iceland's financial crash, December, available at: http:// www.ted.com/talks/halla_tomasdottir.html (accessed 28 November 2012).

Villa, P. \& Smith, M. (2013) Policy in a time of crisis, in: M. Karamessini \& J. Rubery (Eds.) Women and Austerity: The Economic Crisis and the Future for Gender Equality, pp. 273-294 (London: Routledge).

Walby, S. (2011) The Future of Feminism (Cambridge: Polity Press).

Wängneurd, L. \& Sundell, A. (2012) Do politics matter? Women in Swedish local elected assemblies 1970-2010 and gender equality in outcomes, European Political Science Review, 4(1), pp. 97-120.

Waylen, G. (2012) Gender matters in politics, The Political Quarterly, 83(1), pp. 24-32.

Wright, R. (2011) Strengthening the Capacity of the Department of Finance (Dublin: Department of Finance). 